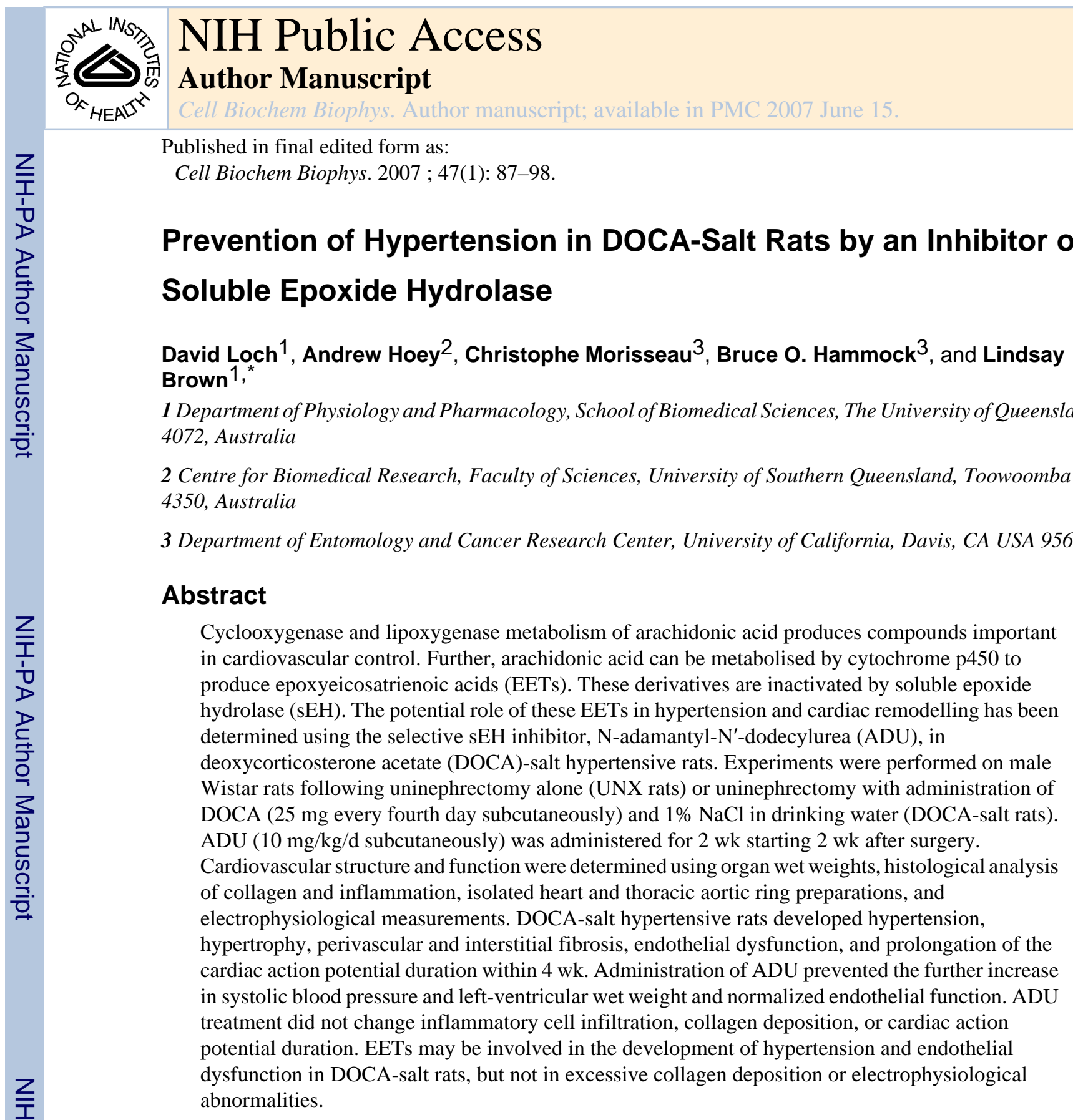

\title{
Index Entries
}

DOCA-salt rats; epoxyeicosatrienoic acids (EETs); hypertension; remodeling; soluble epoxide hydrolase $(\mathrm{sEH})$

\section{INTRODUCTION}

Three major pathways utilizing cyclooxygenase, lipoxygenase, or cytochrome p450 are recognized for the metabolism of arachidonic acid, with cyclooxygenase metabolites such as the prostaglandins and thromboxanes accepted as important modulators of the cardiovascular system (1). Cytochrome p450 metabolizes arachidonic acid in the presence of NADPH and

\footnotetext{
*Author to whom all correspondence and reprint requests should be addressed. E-mail: 1.brown@uq.edu.au
} 
oxygen to epoxyeicosatrienoic acids (EETs) and hydroxy-eicosatetraenoic acids (HETEs). EETs can be further metabolized to dihydroxyeicosatrienoic acids (DHETs) by soluble epoxide hydrolase (sEH) to attenuate or abrogate their biological responses (2). The EETs and HETEs may be important mediators in hypertension, cardiovascular disease, and inflammation (2).

Increasing EET concentrations in vivo represents a potential approach to the treatment of cardiovascular disease. After release from endothelial cells, EETs have multiple physiological effects in the cardiovascular system, including stimulation of calcium-activated potassium channels, hyperpolarization and relaxation of vascular smooth muscle cells (3), protection of the myocardium from ischemia-reperfusion injury (4), fibrinolytic activity (5), and decreased vascular smooth muscle cell migration (6). EETs also impede adhesion molecule expression on endothelial cells via inhibition of cytokine-induced activation of the transcription factor

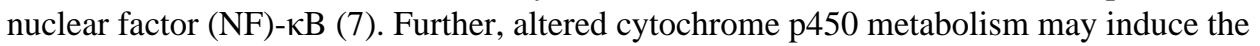
development of hypertension and cardiovascular remodeling (8-11). Cytochrome $\mathrm{p} 450$ metabolism of arachidonic acid was altered in response to deoxycorticosterone acetate (DOCA) treatment (12), dietary salt loading (13-15), and in the remaining kidney after uninephrectomy (16).

Understanding the roles of EETs requires the availability of selective and stable inhibitors of the cytochrome p450 pathway of the metabolism of arachidonic acid. Substituted urea compounds are structural analogs of EET that act as potent, competitive, and tight binding inhibitors of sEH (17). These compounds attenuated vascular smooth muscle cell proliferation (18), decreased systolic blood pressure in the spontaneously hypertensive rat (SHR) and angiotensin II-infusion model (19-21) and protected the kidney (22), all with an associated elevation of EET concentrations.

This study has administered the selective sEH inhibitor, $\mathrm{N}$-adamantyl-N'-dodecylurea (ADU), to DOCA-salt hypertensive rats to determine possible antihypertensive and cardiovascular protective roles by measurement of the changes in cardiovascular structure and function.

\section{METHODS}

\section{Ethical Clearance}

All experimentation was approved by the Animal Experimentation Ethics Committee of The University of Queensland under the guidelines of the National Health and Medical Research Council of Australia.

\section{N-Adamantyl-N'-Dodecylurea}

To a stirred solution of $0.61 \mathrm{~g}(3.3 \mathrm{mmol})$ of dodecylamine in $5 \mathrm{~mL}$ of hexanes was added 0.53 $\mathrm{g}(3.0 \mathrm{mmol})$ of adamantyl isocyanate dissolved in $5 \mathrm{~mL}$ of hexane. After stirring at room temperature for $1 \mathrm{~h}$, a white solid was obtained, which was recrystallized twice from hexanes. The resulting white crystal $(1.05 \mathrm{~g}$; yield: $97 \%)$ had a melting point of $104.0-105.0^{\circ} \mathrm{C} .{ }^{1} \mathrm{H}-$ NMR: $\delta(\mathrm{CDCl} 3) 0.88(3 \mathrm{H}, \mathrm{t}, J=6.9 \mathrm{~Hz}), 1.16-1.36(16 \mathrm{H}, \mathrm{m}), 1.44-1.49(2 \mathrm{H}, \mathrm{m}), 1.58-$ 1.59 (2 H, m), 1.66-1.68 (6 H, m), 1.90-1.96 (6H, m), 2.05-2.07 (3 H, m), 3.09 (2 H, q, J = $6.9 \mathrm{~Hz}), 4.02(2 \mathrm{H}, \mathrm{bs}) \mathrm{ppm}$. Liquid chromatography (LC)-mass spectrometry (MS) $\mathrm{m} / \mathrm{z}$ (relative intensity): $135.3\left(100,\left[\mathrm{M}-\mathrm{C}_{13} \mathrm{H}_{27} \mathrm{~N}_{2} \mathrm{O}\right]+\right), 186.2\left(3[\mathrm{M}-\mathrm{C} 11 \mathrm{H} 16 \mathrm{NO}+2 \mathrm{H}]^{+}\right), 363.3(9,[\mathrm{M}$ $+\mathrm{H}]^{+}$). The chemical structure of ADU is displayed in Fig. 1. ADU inhibited mouse and human sEH by $50 \%$ at $0.05 \pm 0.01 \mu \mathrm{M}$ and $0.10 \pm 0.01 \mu \mathrm{M}$ respectively, as measured by methods described previously (17). ADU $(500 \mu \mathrm{M})$ did not inhibit microsomal epoxide hydrolase, other cytochrome p450 enzymes or esterases. 


\section{DOCA-Salt Hypertensive Rats}

Male Wistar rats weighing 300-330 g ( 8 wk old) were obtained from the Central Animal Breeding House of The University of Queensland. All rats were uninephrectomied under anesthesia with intraperitoneal tiletamine $(25 \mathrm{mg} / \mathrm{kg})$ and zolazepam $(25 \mathrm{mg} / \mathrm{kg})\left(\right.$ Zoletil $\left.^{\circledR}\right)$ combined with xylazine $(10 \mathrm{mg} / \mathrm{kg})\left(\right.$ Ilium Xylazil $\left.{ }^{\circledR}\right)$. Kidneys were visualized by a left lateral abdominal incision. The left kidney was removed after ligation of adjoining renal vasculature and ureter with sutures. The capsule was removed from the left kidney, which was then weighed. Uninephrectomized rats were given either no further treatment (UNX rats) or $1 \%$ $\mathrm{NaCl}$ in the drinking water with subcutaneous injections of DOCA $(25 \mathrm{mg}$ in $0.4 \mathrm{~mL}$ dimethylformamide every fourth day) (DOCA-salt rats). After $14 \mathrm{~d}$, rats received daily subcutaneous injections of ADU $(10 \mathrm{mg} / \mathrm{kg})$ for a further $14 \mathrm{~d}$. The dosage of ADU was chosen based on previous studies using related and similarly potent sEH inhibitors in rats $(19,21,22)$. Experiments were performed $28 \mathrm{~d}$ after surgery.

\section{Assessment of Physiological Parameters}

Systolic blood pressure was measured by tail-cuff plethysmography in rats lightly anesthetized with intraperitoneal tiletamine $(10 \mathrm{mg} / \mathrm{kg})$ and zolazepam $(10 \mathrm{mg} / \mathrm{kg})$. Rats were euthanized with pentobarbitone ( $200 \mathrm{mg} / \mathrm{kg}$ intraperitoneally). Blood was collected from the abdominal vena cava, just caudal to the insertion of renal veins, into heparinized tubes, centrifuged, and the plasma immediately frozen. Plasma sodium and potassium concentrations were measured by flame photometry. The heart and right kidney were removed and weighed immediately after death and their weights expressed as a ratio of the tissue weight (mg) to the total body weight (g).

\section{Isolated Langendorff Heart Preparation}

Rats were anaesthetized with sodium pentobarbitone ( $100 \mathrm{mg} / \mathrm{kg}$ intraperitoneally) and heparin (200 IU) was administered via the femoral vein. After allowing two minutes for the heparin to circulate, the heart was excised and placed in cooled $\left(0^{\circ} \mathrm{C}\right)$ crystalloid perfusate (modified Krebs-Henseleit solution of the following composition in $\mathrm{mM}$ : NaCl 119.1, $\mathrm{KCl} 4.75, \mathrm{MgSO} 4$ $1.19, \mathrm{KH}_{2} \mathrm{PO}_{4} 1.19, \mathrm{CaCl}_{2} 2.16, \mathrm{NaHCO}_{3} 25.0$, glucose 11.0). A cannula was then placed in the heart with its tip immediately above the coronary ostia of the aortic stump. The cannula was used to perfuse the heart in a non-recirculating Langendorff fashion at $100 \mathrm{~cm}$ of hydrostatic pressure. The perfusate temperature was maintained at $37^{\circ} \mathrm{C}$ and bubbled with $95 \% \mathrm{O} 2 / 5 \%$ $\mathrm{CO} 2$. The apex of the heart was pierced to facilitate thebesian drainage and paced at $250 \mathrm{bpm}$.

Left-ventricular developed pressure was measured using a balloon catheter inserted into the left ventricle through the mitral orifice. The catheter was connected via a three-way tap to a micrometer syringe and to a MLT844 Physiological Pressure Transducer (ADInstruments) and PowerLab data acquisition unit (ADInstruments). The outer diameter of the catheter was similar to the mitral annulus to prevent ejection of the balloon during the systolic phase. After a 5-min stabilization period, steady-state left-ventricular pressure was recorded from isovolumetrically beating hearts. Increments in balloon volume were applied to the heart with left ventricular end-diastolic pressure recorded at approx 0, 5, 10, 15, 20, and $30 \mathrm{mmHg}$. At the end of the experiment, the atria and right ventricle were dissected away leaving the left ventricle and septum, which were blotted dry then weighed. Myocardial diastolic stiffness was calculated as the diastolic stiffness constant ( $k$, dimensionless), the slope of the linear relation between tangent elastic modulus $\left(\mathrm{E}\right.$, dyne $\left./ \mathrm{cm}^{2}\right)$ and stress $\left(\sigma\right.$, dyne/cm $\left.{ }^{2}\right)(23)$.

\section{Grading of Inflammation in the Left Ventricle}

The degree of left-ventricular inflammation was determined by blinded semi-quantitative analysis of hematoxylin and eosin-stained transverse sections. Slides were visualised under a 
light microscope with an objective lens of $40 \times$ magnification. A zero to four grading scale was used to quantify the degree of inflammatory cell infiltration in the left ventricle. 0 , no inflammatory cells present; 1 , low level of inflammatory cells throughout the left ventricle; 2 , moderate levels of inflammatory cells throughout the left ventricle and concentrated in mild scarring; 3 , high levels of inflammatory cells throughout the left ventricle and concentrated in moderate scarring; 4, high levels of inflammatory cells throughout the left ventricle and concentrated in heavy scarring.

\section{Quantification of Left Ventricular Collagen}

Collagen content was determined by image analysis of picrosirius red-stained sections of the hearts (24). In brief, transverse sections were stored initially in Telly's fixative $(100 \mathrm{~mL} 70 \%$ ethanol; $5 \mathrm{~mL}$ glacial acetic acid; $10 \mathrm{~mL}$ formaldehyde) for $3 \mathrm{~d}$, then transferred to modified Bouin's solution ( $85 \mathrm{~mL}$ saturated picric acid; $5 \mathrm{~mL}$ glacial acetic acid; $10 \mathrm{~mL} 40 \%$ formaldehyde) for $2 \mathrm{~d}$, then stored in $70 \%$ ethanol.

Sections were subsequently embedded in wax and sliced into $10-\mu \mathrm{m}$ sections. These were stained with picrosirius red ( $0.1 \%$ Sirius Red F3BA in picric acid). Slides were left in $0.2 \%$ phosphomolybdic acid for $5 \mathrm{~min}$, washed, left in picrosirius red for $90 \mathrm{~min}$, then in $1 \mathrm{mM} \mathrm{HCl}$ for 2 min and 70\% ethanol for $45 \mathrm{~s}$. The stained sections were mounted with Depex and visualized using a Biorad MRC-1024 confocal laser-scanning microscope with a Red/Texas Red filter with excitation at $568 \mathrm{~nm}$ and green emission at $609 \mathrm{~nm}$. Images were acquired with an objective lens of $40 \times$ magnification and quantified using NIH-image software (National Institute of Health, MD). At least four areas from each heart were analyzed and collagen levels expressed as a percentage of red area in each image.

\section{Width of Media in Thoracic Aorta}

The width of the media in the thoracic aorta of rats was measured by image analysis of picrosirius red-stained sections. Section preparation, staining, image acquisition, and analysis were similar to those mentioned above. Three different areas of each aorta were measured and the results averaged.

\section{Isolated Thoracic Aortic Rings}

Thoracic aortic rings ( 4 mm in length) were suspended with a resting tension of $10 \mathrm{mN}$. Cumulative concentration-response curves were performed for noradrenaline and either acetylcholine or sodium nitroprusside in the presence of a submaximal ( 70\%) contraction to noradrenaline.

\section{Microelectrode Studies of Isolated Left-Ventricular Papillary Muscles}

Electrophysiological recordings of cardiac action potentials were obtained by microelectrode single cell impalements of ex vivo, left-ventricular papillary muscles. Rats were euthanized by carbon dioxide inhalation with subsequent exsanguination. The heart was removed and placed in chilled Tyrode's physiological salt solution (in mM: $\mathrm{NaCl} 136.9, \mathrm{KCl} 5.4, \mathrm{MgCl}_{2} \cdot \mathrm{H}_{2} \mathrm{O}$ 1.0, $\mathrm{NaH}_{2} \mathrm{PO}_{4} .2 \mathrm{H}_{2} \mathrm{O} 0.4, \mathrm{NaHCO}_{3} 22.6, \mathrm{CaCl}_{2} .2 \mathrm{H}_{2} \mathrm{O} 1.8$, glucose 5.5, ascorbic acid $0.3, \mathrm{Na}_{2}-$ EDTA 0.05 ) bubbled with $95 \% \mathrm{O}_{2} / 5 \% \mathrm{CO}_{2}$, where the left-ventricular papillary muscles were promptly dissected out. A stainless steel hook was placed through the valvular end of the papillary muscle, and a $30-G$ needle was used to fix the apical end. The needle was subsequently embedded into a rubber base placed in a $1.0-\mathrm{mL}$ experimental chamber continuously perfused with carbogenated, warm $\left(35 \pm 0.5^{\circ} \mathrm{C}\right)$ Tyrode's solution at approx $3 \mathrm{~mL} / \mathrm{min}$. The hook was attached to a modified sensor element (SensoNor AE801) connected to an amplifier (World Precision Instruments, TBM-4). The muscle was stretched slowly to the required preload (3$5 \mathrm{mN}$ ). Papillary contractions were induced by field stimulation (Grass SD-9) via electrodes 
on each side of the muscle (stimulation frequency $1 \mathrm{~Hz}$; pulse width $0.5 \mathrm{~ms}$; stimulus strength $20 \%$ above threshold). The muscle was allowed to equilibrate for $30 \mathrm{~min}$ and was then impaled with a micro-electrode (World Precision Instruments, filamented borosilicate glass, outer diameter $1.5 \mathrm{~mm}$ ) with a tip resistance of 5-15 $\mathrm{M} \Omega$ when filled with $3 \mathrm{M} \mathrm{KCl}$. Perfusion and recording then continued for another $30 \mathrm{~min}$. Cardiac action potential parameters measured were cardiac action potential duration (APD) at $20 \%, 50 \%$, and $90 \%$ of repolarization (APD20, ADP50, and APD90 respectively), action potential amplitude and resting membrane potential. The reference electrode was an $\mathrm{Ag} / \mathrm{AgCl}$ electrode. A Cyto 721 electrometer (World Precision Instruments) was used to record bioelectrical activity. All signals were recorded via a PowerLab $4 \mathrm{~S}$ data acquisition unit (ADInstruments). Data were acquired, derived and analysed using Chart 4.3 software (ADInstruments).

\section{Data Analysis}

All results are given as mean \pm SEM. The negative log EC50 of the increase in force of contraction in $\mathrm{mN}$ was determined from the concentration giving half-maximal responses in individual concentration-response curves. These results were analyzed by one-way analysis of variance followed by the Tukey posttest to determine differences between treatment groups; $\mathrm{p}<0.05$ was considered significant.

\section{Drugs}

Deoxycorticosterone acetate, 4-aminopyridine, acetylcholine, sodium nitroprusside, and noradrenaline were purchased from Sigma Chemical Company, St Louis, MO. Noradrenaline, sodium nitroprusside and acetylcholine were dissolved in distilled water; ADU and deoxycorticosterone acetate were dissolved in dimethylformamide with mild heating.

\section{RESULTS}

Over the 4-wk treatment period, DOCA-salt rats developed significant cardiovascular remodeling shown as ventricular hypertrophy, collagen deposition, endothelial dysfunction, and cardiac action potential duration prolongation (Table 1) (Fig. 2). These rats gained significantly less weight than UNX controls and became hypokalemic with an increased inflammatory cell infiltration as well as an increased diastolic stiffness of the left ventricle (Table 1) (Fig. 3). Treatment with ADU for 2 wk starting 2 wk after surgery prevented any further increase in blood pressure (Fig. 2) and left-ventricular wet weight (Table 1) without changes in blood electrolytes, body weight, inflammatory cell infiltration, collagen deposition, or diastolic stiffness (Table 1). In addition, DOCA-salt rats showed medial hypertrophy, which was prevented by ADU intervention (Fig. 4).

The maximal contractile responses to noradrenaline and relaxant responses to sodium nitroprusside in isolated thoracic aortic rings were unchanged in DOCA-salt rats and also after treatment with ADU (Fig. 5A,C). In contrast, the maximal relaxant responses to acetylcholine were reduced in DOCA-salt rats after $4 \mathrm{wk}$. ADU treatment normalized this endotheliumdependent relaxation response to acetylcholine in DOCA- salt rats (Fig. 5B).

DOCA-salt treatment caused significant cardiac action potential prolongation at APD90 whereas resting membrane potential and cardiac action potential amplitude were unchanged. These parameters were unchanged by ADU treatment (Table 2).

\section{DISCUSSION}

The EETs are metabolites of arachidonic acid that are inactivated by sEH. The high inhibitory potency of the substituted urea compound, ADU, on mouse and human sEH and lack of activity 
on cytochrome p450s and esterases suggest that this compound is a highly selective sEH inhibitor. The synergism between the inhibitors of sEH and slow release formulations of the natural EETs supports the hypothesis that these inhibitors are effective by stabilization of these endogenous biological mediators (25). This study demonstrates that administration of ADU lowered systolic blood pressure, normalized vascular endothelial function, and attenuated leftventricular hypertrophy in the DOCA-salt model of hypertension in rats, supporting a vascularselective role for sEH in the pathogenesis of this model and a role for EETs in lowering an increased blood pressure.

Sinal et al. (26) first showed that sEH may have a role in blood pressure regulation, reporting that the systolic blood pressure of sEH-knockout male mice was lower, with a resultant reduction in the renal formation of EETs and DHETs, compared with wild-type mice. The development of potent, competitive urea-based sEH inhibitors (17) and their subsequent use in animal models of cardiovascular disease $(19,21,22)$ has highlighted the potential importance of this enzyme in hypertension. As an example, a single dose of $\mathrm{N}, \mathrm{N}^{\prime}$-dicyclohexylurea, another urea-based sEH inhibitor similar to ADU, lowered systolic blood pressure and urinary DHET excretion in the SHR, with the antihypertensive effect lasting less than $24 \mathrm{~h}$ (21). Furthermore, treatment with the related compound 1-cyclohexyl-3-dodecyl urea for 4 to $10 \mathrm{~d}$ in angiotensininduced hypertensive rats was effective in reducing blood pressure $(19,22)$. The response to sEH inhibitors is assumed to be due to the resultant increase in plasma EET concentrations $(19,21,22)$. Potential mechanisms for the antihypertensive action of sEH inhibitors such as ADU include direct activation by EETs of vascular smooth muscle potassium channels (27) and inhibition of renal $\mathrm{Na}^{+}-\mathrm{K}^{+}$-ATPase (28) and $\mathrm{Na}^{+}-\mathrm{K}^{+}-2 \mathrm{Cl}^{-}$cotransporter (29).

Overexpression of sEH may contribute to cardiovascular disease. An increased sEH gene expression and protein abundance have been established in the SHR $(21,30)$ and angiotensininduced hypertension $(19,22)$. This suggests that overactive conversion of EETs to their corresponding diols could diminish the antihypertensive, anti-inflammatory, and antiproliferative responses to EETs, contributing to the pathogenesis of cardiovascular disease in these models. Altered sEH enzymatic activity may be responsible for pregnancy-induced hypertension, with dramatic rises observed in the excretion of DHETs in this condition (31). Allelic variation in the sEH gene may have implications in the development of coronary artery calcification (32) and familial hypercholesterolemia (33) and hence atherosclerosis.

The effects of EETs on vascular proliferation are contradictory. The sEH inhibitor 1cyclohexyl-3-dodecylurea inhibited human vascular smooth muscle cell proliferation in vitro, with no evidence of cellular toxicity or apoptosis in treated cells, an effect mimicked by EETs (18). However, EETs showed mitogenic effects in vascular smooth muscle cells (34). An antimigratory action of EETs has been suggested in rat aortic smooth muscle cells without pro- or anti-proliferative effects on platelet-derived growth factor (PDGF)-stimulated mitogenesis (6). Vascular hypertrophy and structural remodelling of vessel walls in hypertension exacerbate the condition by increasing systemic vascular resistance $(35,36)$. The decreased vascular remodeling following ADU treatment may be a consequence of the reduced systolic blood pressure or a direct inhibition of vascular smooth muscle cell proliferation.

Endothelial dysfunction, usually shown as a reduced response to acetylcholine, is characteristic of hypertension $(37,38)$, including the DOCA-salt model (39). Reduction in the blood pressure of DOCA-salt animals has resulted in improved endothelium-dependent vasodilator responses (40). Weintraub and associates (41) demonstrated that treatment of coronary endothelial cells with an sEH inhibitor blocked the conversion of EETs to DHETs and subsequently augmented EET incorporation into the phosholipid membrane bilayer. They also demonstrated in the same study that sEH inhibition augmented a 14,15-EET-induced potentiation of endotheliumdependent relaxation to bradykinin in porcine coronary arteries. These results suggest that sEH, 
through regulating EET membrane incorporation, may have a direct role in modulating endothelial function. Thus, the normalization of endothelial-dependent responses in the present study may not only be an indirect response to the prevention of an increase in blood pressure, but also a direct effect of sEH inhibition (and enhanced EET levels) on endothelial function. The relative contribution of either mechanism, however, is beyond the scope of this study.

DOCA-salt hypertension in rats is also characterized by excessive collagen deposition (23) and cardiac action potential duration prolongation (42). ADU did not attenuate these responses, suggesting that EETs have no role in these pathophysiological changes.

In summary, we have shown that administration of the selective sEH inhibitor, ADU, to DOCAsalt hypertensive rats prevented further increases in systolic blood pressure, normalized endothelial dysfunction and attenuated some of the associated cardiovascular remodeling, including left-ventricular and aortic medial hypertrophy. Thus, disease-induced modulation of sEH expression and activity may contribute to the pathogenesis of human and animal cardiovascular disease, which suggests that sEH inhibition to increase EET concentrations is a novel and potentially attractive therapeutic approach to the treatment of hypertension.

\section{Acknowledgements}

This work was supported by grants from NIEHS R37 ES02710, P42 ES04699, P30 ES05707, and NIH R01 HL59699-06A1. A visiting professorship was provided by the Department of Biochemistry, The University of Queensland, Australia, to B.D.H.

\section{References}

1. Fletcher JR. Eicosanoids. Critical agents in the physiological process and cellular injury. Arch Surg 1993;128:1192-1196. [PubMed: 8239981]

2. Roman RJ. P-450 metabolites of arachidonic acid in the control of cardiovascular function. Physiol Rev 2002;82:131-185. [PubMed: 11773611]

3. Capdevila JH, Falck JR. The CYP P450 arachidonic acid monooxygenases: from cell signaling to blood pressure regulation. Biochem Biophys Res Commun 2001;285:571-576. [PubMed: 11453630]

4. Wu S, Chen W, Murphy E, et al. Molecular cloning, expression, and functional significance of a cytochrome P450 highly expressed in rat heart myocytes. J Biol Chem 1997;272:12,551-12,559.

5. Node K, Ruan XL, Dai J, et al. Activation of Galpha s mediates induction of tissue-type plasminogen activator gene transcription by epoxyeicosatrienoic acids. J Biol Chem 2001;276:15,983-15,989.

6. Sun J, Sui X, Bradbury JA, Zeldin DC, Conte MS, Liao JK. Inhibition of vascular smooth muscle cell migration by cytochrome p450 epoxygenase-derived eicosanoids. Circ Res 2002;90:1020-1027. [PubMed: 12016269]

7. Node K, Huo Y, Ruan X, et al. Anti-inflammatory properties of cytochrome P450 epoxygenase-derived eicosanoids. Science 1999;285:1276-1279. [PubMed: 10455056]

8. Muthalif MM, Karzoun NA, Gaber L, et al. Angiotensin II-induced hypertension: contribution of Ras GTPase/Mitogen-activated protein kinase and cytochrome P450 metabolites. Hypertension 2000;36:604-609. [PubMed: 11040243]

9. Messer-Letienne I, Bernard N, Roman RJ, Sassard J, Benzoni D. Cytochrome P-450 arachidonate metabolite inhibition improves renal function in Lyon hypertensive rats. Am J Hypertens 1999;12:398404. [PubMed: 10232500]

10. Sacerdoti D, Escalante B, Abraham NG, McGiff JC, Levere RD, Schwartzman ML. Treatment with tin prevents the development of hypertension in spontaneously hypertensive rats. Science 1989;243:388-390. [PubMed: 2492116]

11. Stec DE, Deng AY, Rapp JP, Roman RJ. Cytochrome P450 4A genotype cosegregates with hypertension in Dahl S rats. Hypertension 1996;27:564-568. [PubMed: 8613204]

12. Lapuerta L, Chacos N, Falck JR, Jacobson H, Capdevila JH. Renal microsomal cytochrome P-450 and the oxidative metabolism of arachidonic acid. Am J Med Sci 1988;295:275-279. [PubMed: 3364462] 
13. Capdevila JH, Wei S, Yan J, et al. Cytochrome P-450 arachidonic acid epoxygenase. Regulatory control of the renal epoxygenase by dietary salt loading. J Biol Chem 1992;267:21,720-21,726. [PubMed: 1370444]

14. Makita K, Takahashi K, Karara A, Jacobson HR, Falck JR, Capdevila JH. Experimental and/or genetically controlled alterations of the renal microsomal cytochrome $\mathrm{P} 450$ epoxygenase induce hypertension in rats fed a high salt diet. J Clin Invest 1994;94:2414-2420. [PubMed: 7989598]

15. Holla VR, Makita K, Zaphiropoulos PG, Capdevila JH. The kidney cytochrome P-450 2C23 arachidonic acid epoxygenase is upregulated during dietary salt loading. J Clin Invest 1999;104:751760. [PubMed: 10491410]

16. Takahashi K, Harris RC, Capdevila JH, et al. Induction of renal arachidonate cytochrome P-450 epoxygenase after uninephrectomy: counterregulation of hyper-filtration. J Am Soc Nephrol 1993;3:1496-1500. [PubMed: 8387830]

17. Morisseau C, Goodrow MH, Dowdy D, et al. Potent urea and carbamate inhibitors of soluble epoxide hydrolases. Proc Natl Acad Sci USA 1999;96:8849-8854. [PubMed: 10430859]

18. Davis BB, Thompson DA, Howard LL, Morisseau C, Hammock BD, Weiss RH. Inhibitors of soluble epoxide hydrolase attenuate vascular smooth muscle cell proliferation. Proc Natl Acad Sci USA 2002;99:2222-2227. [PubMed: 11842228]

19. Imig JD, Zhao X, Capdevila JH, Morisseau C, Hammock BD. Soluble epoxide hydrolase inhibition lowers arterial blood pressure in angiotensin II hypertension. Hypertension 2002;39:690-694. [PubMed: 11882632]

20. Yu Z, Davis BB, Morisseau C, et al. Vascular localization of soluble epoxide hydrolase in the human kidney. Am J Physiol Renal Physiol 2004;286:F720-F726. [PubMed: 14665429]

21. Yu Z, Xu F, Huse LM, et al. Soluble epoxide hydrolase regulates hydrolysis of vasoactive epoxyeicosatrienoic acids. Circ Res 2000;87:992-998. [PubMed: 11090543]

22. Zhao X, Yamamoto T, Newman JW, et al. Soluble epoxide hydrolase inhibition protects the kidney from hypertension-induced damage. J Am Soc Nephrol 2004;15:1244-1253. [PubMed: 15100364]

23. Brown L, Duce B, Miric G, Sernia C. Reversal of cardiac fibrosis in deoxycorticosterone acetate-salt hypertensive rats by inhibition of the renin-angiotensin system. J Am Soc Nephrol 1999;10(Suppl 11):S143-S148. [PubMed: 9892155]

24. Miric G, Dallemagne C, Endre Z, Margolin S, Taylor SM, Brown L. Reversal of cardiac and renal fibrosis by pirfenidone and spironolactone in streptozotocin-diabetic rats. Br J Pharmacol 2001;133:687-694. [PubMed: 11429393]

25. Smith KR, Pinkerton KE, Watanabe T, Pedersen TL, Ma SJ, Hammock BD. Attenuation of tobacco smoke-induced lung inflammation by treatment with a soluble epoxide hydrolase inhibitor. Proc Natl Acad Sci USA 2005;102:2186-2191. [PubMed: 15684051]

26. Sinal CJ, Miyata M, Tohkin M, Nagata K, Bend JR, Gonzalez FJ. Targeted disruption of soluble epoxide hydrolase reveals a role in blood pressure regulation. J Biol Chem 2000;275:40,504-40,510.

27. Hu S, Kim HS. Activation of $\mathrm{K}^{+}$channel in vascular smooth muscles by cytochrome $\mathrm{P} 450$ metabolites of arachidonic acid. Eur J Pharmacol 1993;230:215-221. [PubMed: 8422904]

28. Satoh T, Cohen HT, Katz AI. Intracellular signaling in the regulation of renal Na-K-ATPase. II. Role of eicosanoids. J Clin Invest 1993;91:409-415. [PubMed: 8381820]

29. He H, Podymow T, Zimpelmann J, Burns KD. NO inhibits $\mathrm{Na}^{+}-\mathrm{K}+-2 \mathrm{Cl}-$ cotransport via a cytochrome P-450-dependent pathway in renal epithelial cells (MMDD1). Am J Physiol Renal Physiol 2003;284:F1235-F1244. [PubMed: 12582005]

30. Fornage M, Hinojos CA, Nurowska BW, et al. Polymorphism in soluble epoxide hydrolase and blood pressure in spontaneously hypertensive rats. Hypertension 2002;40:485-490. [PubMed: 12364351]

31. Catella F, Lawson JA, Fitzgerald DJ, FitzGerald GA. Endogenous biosynthesis of arachidonic acid epoxides in humans: increased formation in pregnancy-induced hypertension. Proc Natl Acad Sci USA 1990;87:5893-5897. [PubMed: 2198572]

32. Fornage M, Boerwinkle E, Doris PA, Jacobs D, Liu K, Wong ND. Polymorphism of the soluble epoxide hydrolase is associated with coronary artery calcification in African-American subjects: The Coronary Artery Risk Development in Young Adults (CARDIA) study. Circulation 2004;109:335339. [PubMed: 14732757] 
33. Sato K, Emi M, Ezura Y, et al. Soluble epoxide hydrolase variant (Glu287Arg) modifies plasma total cholesterol and triglyceride phenotype in familial hypercholesterolemia: intrafamilial association study in an eight-generation hyperlipidemic kindred. J Hum Genet 2004;49:29-34. [PubMed: 14673705]

34. Sheu HL, Omata K, Utsumi Y, et al. Epoxyeicosatrienoic acids stimulate the growth of vascular smooth muscle cells. Adv Prostaglandin Thromboxane Leukot Res 1995;23:211-213. [PubMed: 7732837]

35. Karam H, Heudes D, Gonzales MF, Loffler BM, Clozel M, Clozel JP. Respective role of humoral factors and blood pressure in aortic remodeling of DOCA hypertensive rats. Am J Hypertens 1996;9:991-998. [PubMed: 8896651]

36. Owens GK, Rabinovitch PS, Schwartz SM. Smooth muscle cell hypertrophy versus hyperplasia in hypertension. Proc Natl Acad Sci USA 1981;78:7759-7763. [PubMed: 6950415]

37. Konishi M, Su C. Role of endothelium in dilator responses of spontaneously hypertensive rat arteries. Hypertension 1983;5:881-886. [PubMed: 6654451]

38. Luscher TF, Raij L, Vanhoutte PM. Endothelium-dependent vascular responses in nor-motensive and hypertensive Dahl rats. Hypertension 1987;9:157-163. [PubMed: 3818012]

39. Van de Voorde J, Leusen I. Endothelium-dependent and independent relaxation of aortic rings from hypertensive rats. Am J Physiol 1986;250:H711-H717. [PubMed: 3458379]

40. Nunes VW, Fortes ZB, Nigro D, Carvalho MH, Zorn TM, Scivoletto R. Influence of enalapril on the endothelial function of DOCA-salt hypertensive rats. Gen Pharmacol 2000;34:117-125. [PubMed: 10974419]

41. Weintraub NL, Fang X, Kaduce TL, VanRollins M, Chatterjee P, Spector AA. Epoxide hydrolases regulate epoxyeicosatrienoic acid incorporation into coronary endothelial phospholipids. Am J Physiol 1999;277:H2098-H2108. [PubMed: 10564166]

42. Coulombe A, Momtaz A, Richer P, Swynghedauw B, Coraboeuf E. Reduction of calcium-independent transient outward potassium current density in DOCA salt hypertrophied rat ventricular myocytes. Pflugers Arch 1994;427:47-55. [PubMed: 8058475] 


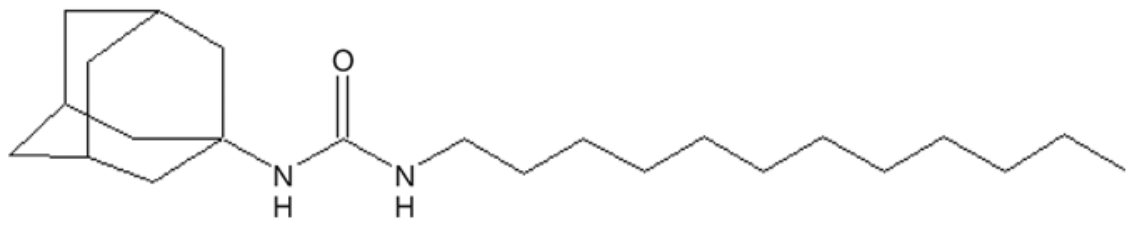

Fig 1.

The chemical structure of $\mathrm{N}$-adamantyl-N'-dodecylurea. 


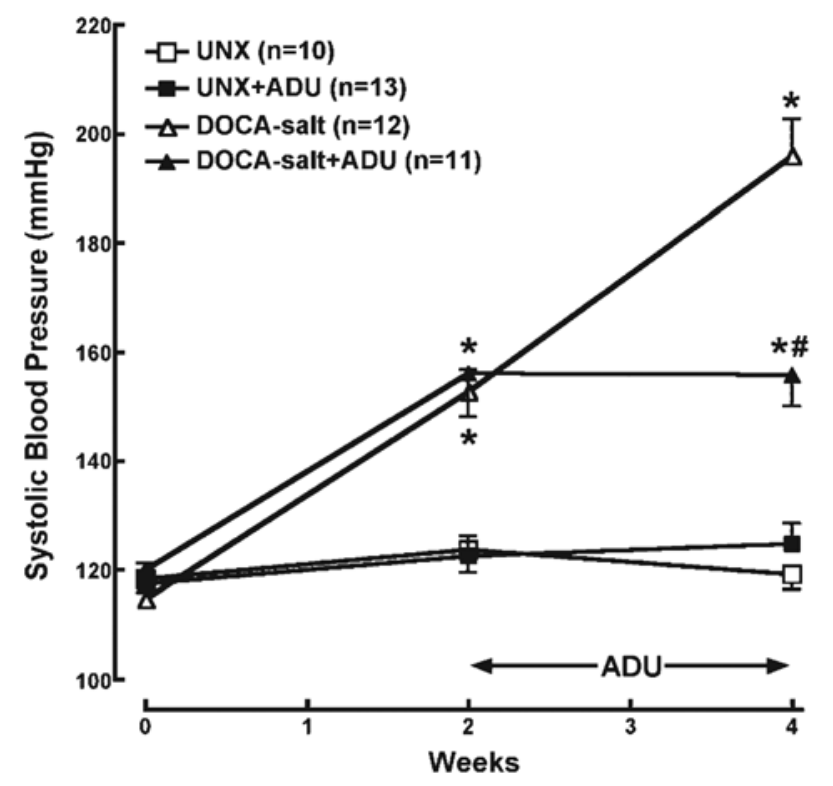

Fig 2.

Effect of soluble epoxide hydrolase inhibition on blood pressure. Data represent the comparison of systolic blood pressure in uninephrectomy (UNX), N-adamantyl-N'dodecylurea (ADU)-treated UNX, deoxycorticosterone acetate (DOCA)-salt hypertensive, and ADU-treated DOCA-salt hypertensive groups over the 4-wk protocol period. Values are mean \pm SEM; *p $<0.05$ vs UNX; \#p < 0.05 vs DOCA-salt (4 wk). 

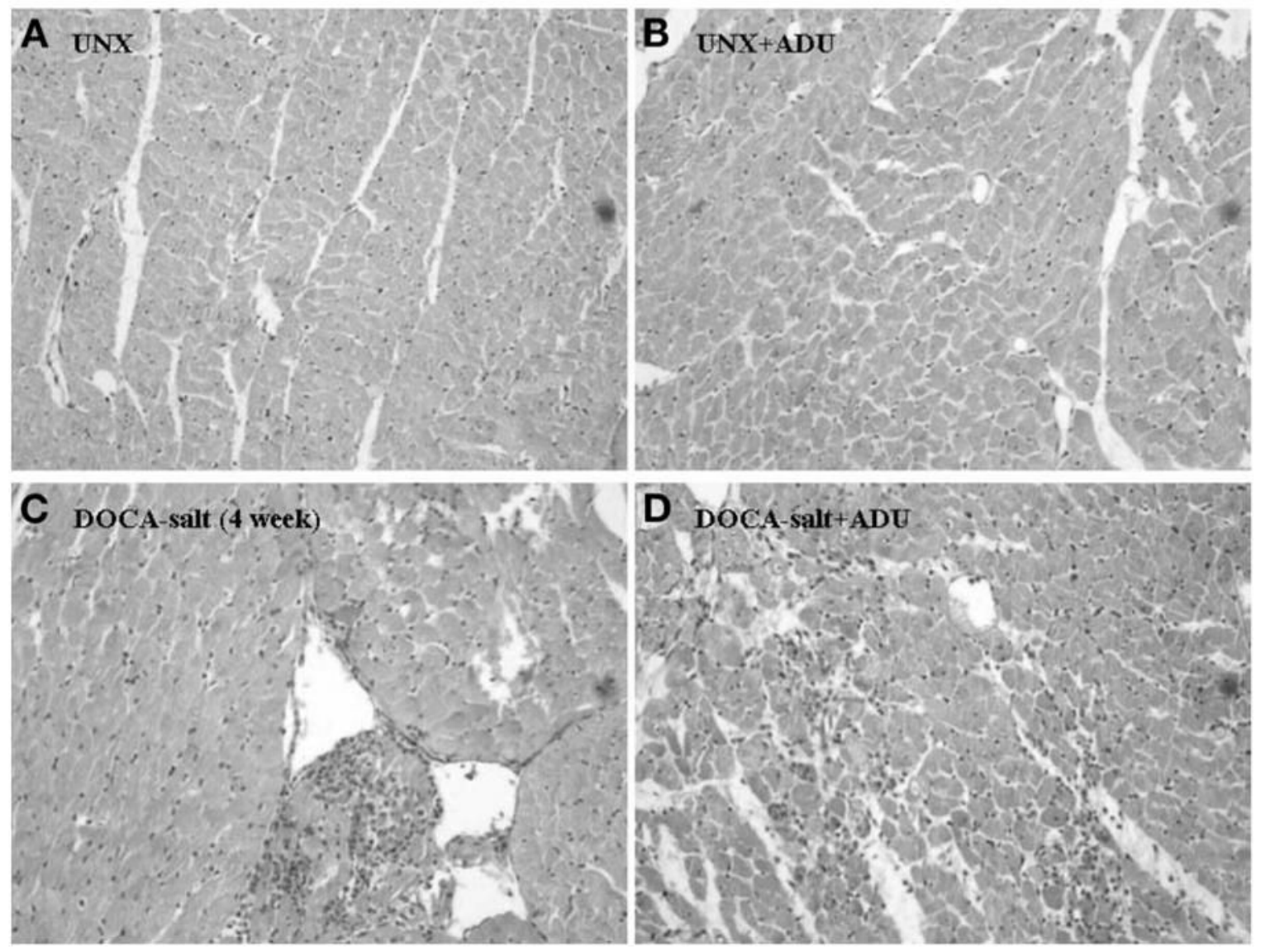

Fig 3.

Effect of soluble epoxide hydrolase inhibition on ventricular remodeling. The panel shows representative confocal microscopy images of hematoxylin and eosin-stained left-ventricular transverse sections at 200× magnification from uninephrectomy (UNX) (A), N-adamantyl-N '-dodecylurea (ADU)-treated UNX (B), deoxycorticosterone acetate (DOCA)-salt (C), and ADU-treated DOCA-salt rats (D). 

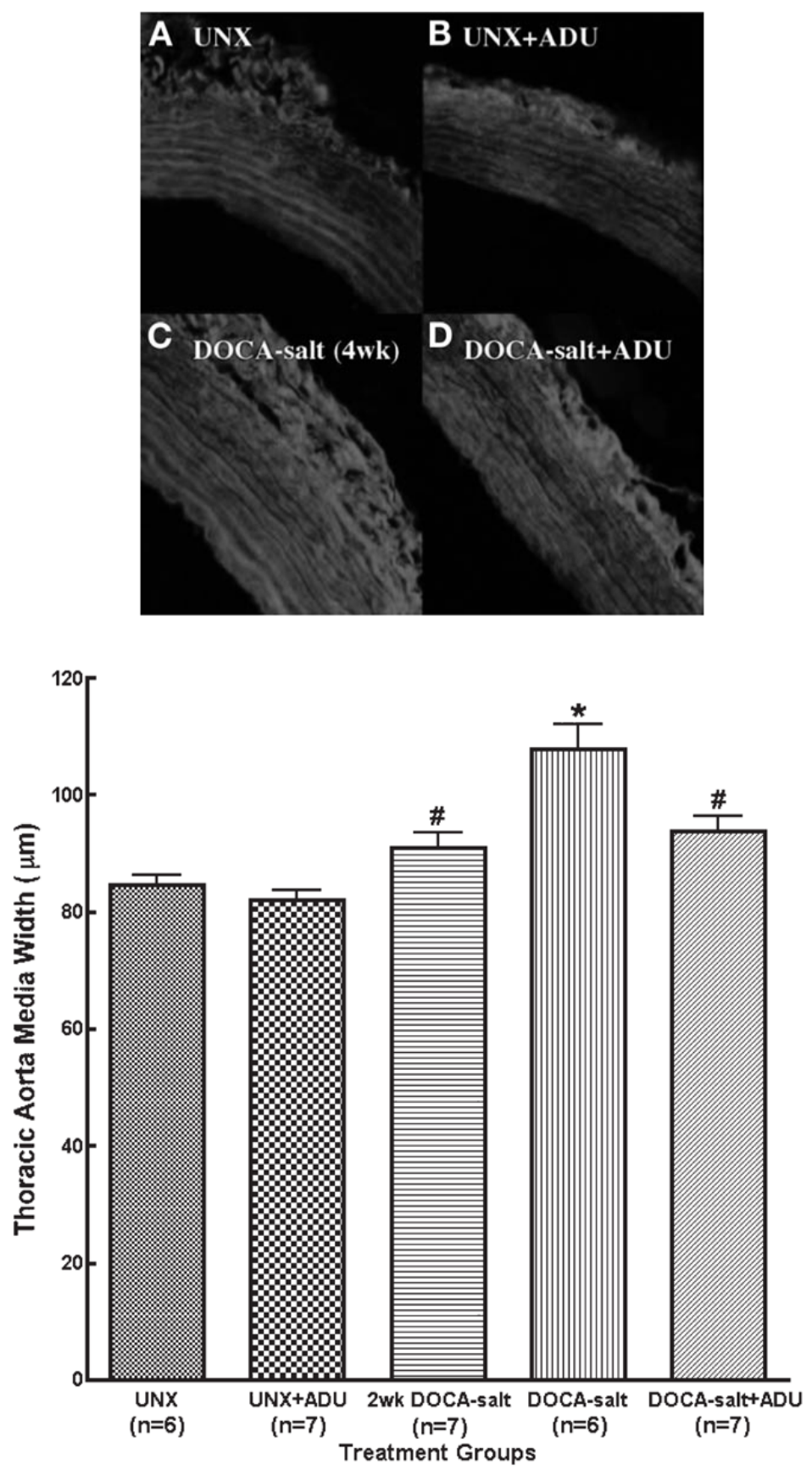

Fig 4.

Effect of soluble epoxide hydrolase inhibition on vascular remodeling. The panel shows representative confocal microscopy images of thoracic aorta cross-sections at $400 \times$ magnification from uninephrectomy (UNX) (A), N-adamantyl-N'-dodecylurea (ADU)-treated UNX (B), deoxycorticosterone acetate (DOCA)-salt (C), and ADU-treated DOCA-salt rats (D). The bar graph illustrates the measured aortic medial widths. Values are mean \pm SEM; *p $<0.05$ vs UNX; \#p < 0.05 vs DOCA-salt (4 wk). 

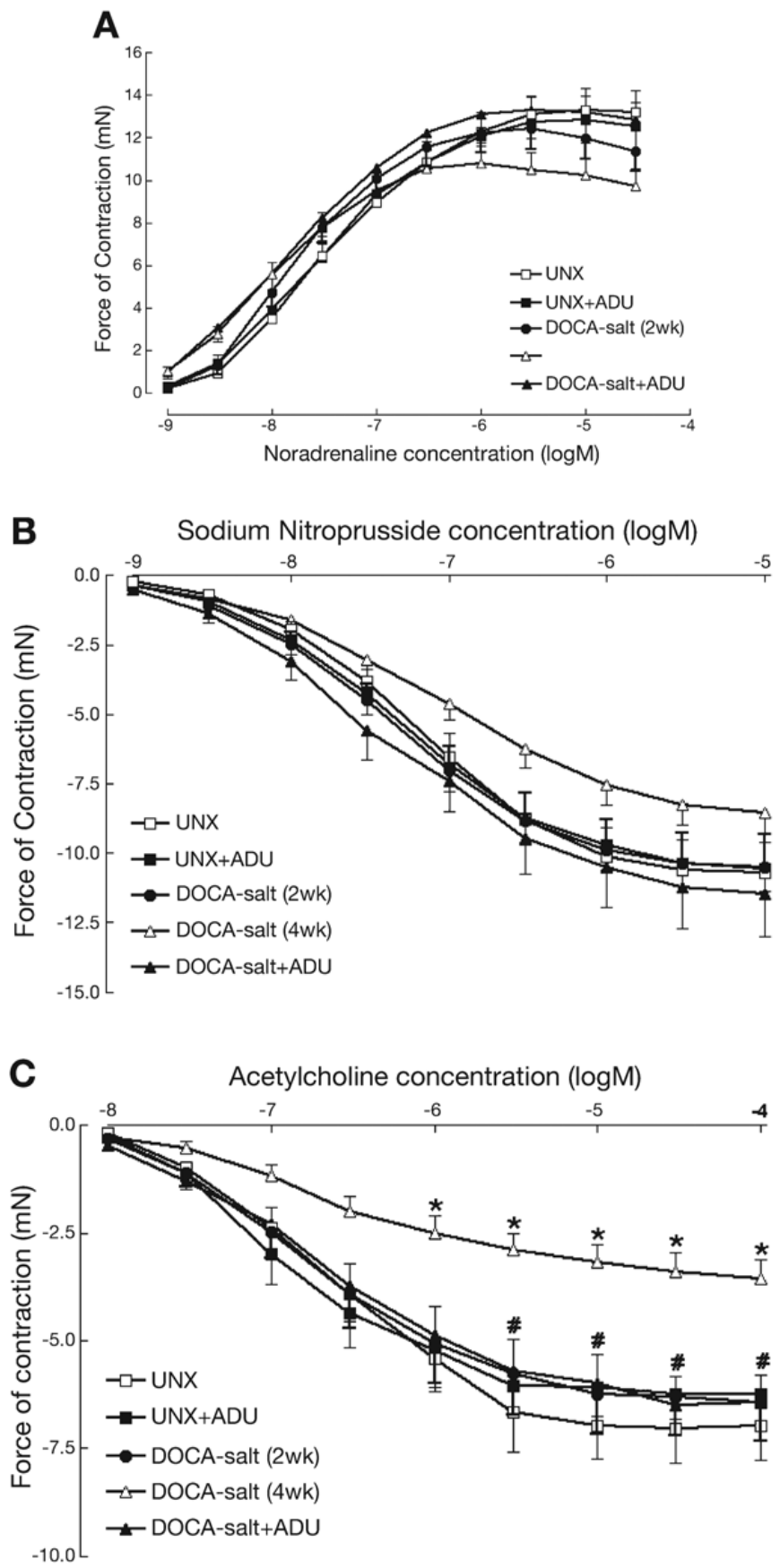

Fig 5.

Concentration-response curves to noradrenaline (A) for uninephrectomy (UNX) (open square, - $\log$ EC50 7.4 $\pm 0.1, \mathrm{n}=14$ ), $\mathrm{N}$-adamantyl-N'-dodecylurea (ADU)-treated UNX (filled square, $-\log$ EC50 $7.5 \pm 0.1, \mathrm{n}=12$ ), 2 wk deoxycorticosterone acetate (DOCA)-salt (filled circle, $-\log$ EC50 7.7 $\pm 0.1, \mathrm{n}=13$ ), DOCA-salt (open triangle, $-\log$ EC50 8.0 $\pm 0.1^{*}, \mathrm{n}=18$ ) and ADU-treated DOCA-salt (filled triangle, $-\log$ EC50 7.8 $\pm 0.1^{*}, \mathrm{n}=13$ ). Concentrationresponse curves to acetylcholine (B) for UNX (open square, $-\log$ EC50 $6.5 \pm 0.2, \mathrm{n}=14$ ), ADU-treated UNX (filled square, $-\log$ EC50 $6.7 \pm 0.2, \mathrm{n}=11$ ), 2 wk DOCA-salt (filled circle, $-\log$ EC50 $6.6 \pm 0.1, \mathrm{n}=13$ ), DOCA-salt (open triangle, $-\log$ EC50 $6.6 \pm 0.1, \mathrm{n}=18$ ) and ADU-treated DOCA-salt (filled triangle, $-\log$ EC50 6.6 $\pm 0.1, n=13$ ). Concentration-response 
curves to sodium nitroprusside (C) for UNX (open square, $-\log$ EC50 7.2 $\pm 0.1, \mathrm{n}=14$ ), ADUtreated UNX (filled square, $-\log$ EC50 7.2 $\pm 0.1, \mathrm{n}=13$ ), 2 wk DOCA-salt (filled circle, $-\log$ EC50 7.4 $\pm 0.1, \mathrm{n}=12$ ), DOCA-salt (open triangle, $-\log$ EC50 $7.1 \pm 0.1, \mathrm{n}=18$ ) and ADUtreated DOCA-salt (filled triangle, $-\log$ EC50 7.4 $\pm 0.1, n=13$ ); ${ }^{*} p<0.05$ vs UNX; \#p $<0.05$ vs DOCA-salt (4 wk). 
Table 1

Physiological Parameters in Uninephrectomy (UNX), Deoxycorticosterone Acetate (DOCA)-Salt, and Nadamantyl-N'-dodecylurea (ADU)-Treated Rats

\begin{tabular}{|c|c|c|c|c|c|}
\hline & UNX & $\mathbf{U N X}+\mathbf{A D U}$ & $\begin{array}{l}\text { DOCA- } \\
\text { salt ( } 2 \text { wk) }\end{array}$ & $\begin{array}{l}\text { DOCA- } \\
\text { salt (4 wk) }\end{array}$ & $\begin{array}{c}\text { DOCA- } \\
\text { salt +ADU }\end{array}$ \\
\hline Initial body weight ( $\mathrm{g}$ ) & $\begin{array}{c}321 \pm 4 \\
(\mathrm{n}=8)\end{array}$ & $313 \pm 6(n=8)$ & $314 \pm 2(n=12)$ & $321 \pm 5(n=10)$ & $308 \pm 3(n=13)$ \\
\hline Final body weight(g) & $\begin{array}{l}380 \pm 7 \\
(\mathrm{n}=8)\end{array}$ & $383 \pm 7(n=8)$ & $332 \pm 7^{a}(\mathrm{n}=12)$ & $335 \pm 6^{a}(\mathrm{n}=10)$ & $314 \pm 6^{a}(\mathrm{n}=13)$ \\
\hline $\begin{array}{l}\mathrm{LV}+\text { septum weight relative to } \\
\text { body weight }(\mathrm{mg} / \mathrm{g})\end{array}$ & $\begin{array}{c}1.99 \pm 0.04 \\
(\mathrm{n}=8)\end{array}$ & $\begin{array}{c}1.85 \pm 0.04 \\
(n=8)\end{array}$ & $\begin{array}{l}2.27 \pm 0.05^{a} b \\
\quad(\mathrm{n}=12)\end{array}$ & $\begin{array}{l}2.71 \pm 0.08^{a} \\
\quad(\mathrm{n}=10)\end{array}$ & $\begin{array}{l}2.45 \pm 0.06^{a b} \\
(\mathrm{n}=13)\end{array}$ \\
\hline $\begin{array}{l}\mathrm{LV}+\text { septum weight relative to } \\
\text { tibial length }(\mathrm{g} / \mathrm{m})\end{array}$ & $\begin{array}{c}18.3 \pm 0.5 \\
(\mathrm{n}=8)\end{array}$ & $\begin{array}{c}17.1 \pm 0.2 \\
(\mathrm{n}=8)\end{array}$ & $\begin{array}{c}19.3 \pm 0.8^{b} \\
(\mathrm{n}=12)\end{array}$ & $\begin{array}{c}22.6 \pm 0.7^{a} \\
(\mathrm{n}=11)\end{array}$ & $18.9 \pm 0.4(n=13)$ \\
\hline $\begin{array}{l}\text { Kidney weight relative to body } \\
\text { weight }(\mathrm{mg} / \mathrm{g})\end{array}$ & $\begin{array}{l}5.20 \pm 0.28 \\
\quad(n=8)\end{array}$ & $\begin{array}{l}5.40 \pm 0.15 \\
\quad(n=8)\end{array}$ & $\begin{array}{c}7.51 \pm 0.25^{a} b \\
(\mathrm{n}=12)\end{array}$ & $\begin{array}{l}8.85 \pm 0.39^{a} \\
\quad(\mathrm{n}=11)\end{array}$ & $\begin{array}{l}9.46 \pm 0.31^{a} \\
\quad(\mathrm{n}=13)\end{array}$ \\
\hline $\begin{array}{l}\text { Plasma } \mathrm{Na}^{+} \text {concentration } \\
(\mathrm{mM})\end{array}$ & $\begin{array}{c}133.6 \pm 1.6 \\
(\mathrm{n}=8)\end{array}$ & $\begin{array}{l}134.2 \pm 1.1 \\
(\mathrm{n}=10)\end{array}$ & $\begin{array}{c}136.5 \pm 0.3 \\
(\mathrm{n}=10)\end{array}$ & $\begin{array}{c}138.2 \pm 0.7 \\
(\mathrm{n}=10)\end{array}$ & $\begin{array}{c}134.6 \pm 1.6 \\
(\mathrm{n}=10)\end{array}$ \\
\hline Plasma $\mathrm{K}^{+}$concentration $(\mathrm{mM})$ & $\begin{array}{c}4.0 \pm 0.4 \\
(\mathrm{n}=8)\end{array}$ & $\begin{array}{l}3.7 \pm 0.4 \\
(\mathrm{n}=10)\end{array}$ & $2.2 \pm 0.2^{a}(\mathrm{n}=10)$ & $2.3 \pm 0.2^{a}(\mathrm{n}=10)$ & $2.3 \pm 0.2^{a}(\mathrm{n}=10)$ \\
\hline Inflammatory score & $\begin{array}{l}0.67 \pm 0.21 \\
\quad(n=6)\end{array}$ & $\begin{array}{c}0.36 \pm 0.18 \\
\quad(n=7\end{array}$ & $\begin{array}{c}2.36 \pm 0.50^{a} \\
(\mathrm{n}=7)\end{array}$ & $\begin{array}{c}3.08 \pm 0.37^{a} \\
\quad(\mathrm{n}=6)\end{array}$ & $\begin{array}{l}3.14 \pm 0.24^{a} \\
\quad(\mathrm{n}=7)\end{array}$ \\
\hline Interstitial fibrosis (\%area) & $\begin{array}{l}2.61 \pm 0.24 \\
\quad(n=6)\end{array}$ & $\begin{array}{c}2.70 \pm 0.30 \\
(n=7\end{array}$ & $\begin{array}{c}4.38 \pm 0.35^{a} \\
(\mathrm{n}=6)\end{array}$ & $\begin{array}{c}5.41 \pm 0.65^{a} \\
(\mathrm{n}=6)\end{array}$ & $\begin{array}{c}5.21 \pm 0.21^{a} \\
(\mathrm{n}=7)\end{array}$ \\
\hline Perivascular Fibrosis (\%area) & $\begin{array}{c}22.5 \pm 1.8 \\
(\mathrm{n}=6)\end{array}$ & $\begin{array}{l}21.2 \pm 1.1 \\
(\mathrm{n}=7)\end{array}$ & $27.1 \pm 0.8^{a}(\mathrm{n}=6)$ & $31.3 \pm 1.7^{a}(\mathrm{n}=6)$ & $29.5 \pm 1.2^{a}(\mathrm{n}=7)$ \\
\hline Diastolic Stiffness Constant $(k)$ & $\begin{array}{l}22.5 \pm 0.4 \\
(\mathrm{n}=7)\end{array}$ & $\begin{array}{l}22.4 \pm 0.3 \\
(\mathrm{n}=7)\end{array}$ & $22.1 \pm 0.3(\mathrm{n}=8)$ & $\begin{array}{l}24.8 \pm 0.6^{a} \\
(\mathrm{n}=12)\end{array}$ & $25.9 \pm 0.6^{a}(\mathrm{n}=8)$ \\
\hline
\end{tabular}

$a_{\mathrm{p}}<0.05$ compared to UNX.

$b_{\mathrm{p}}<0.05$ compared to DOCA-salt $(4 \mathrm{wk})$. 
Table 2

Cardiac Electrophysiological Parameters in Uninephrectomy (UNX), Deoxycorticosterone Acetate (DOCA)Salt, and N-Adamantyl-N'-Dodecylurea (ADU)-Treated Rats

\begin{tabular}{|c|c|c|c|c|c|}
\hline & UNX & $\mathbf{U N X}+\mathbf{A D U}$ & DOCA-salt ( 2 week) & DOCA-salt (4 week) & DOCA-salt +ADU \\
\hline $\begin{array}{l}\text { Resting } \\
\text { Membrane } \\
\text { Potential (mV) }\end{array}$ & $-76 \pm 2(n=6)$ & $-77 \pm 2(n=7)$ & $-68 \pm 3(n=7)$ & $-71 \pm 1(\mathrm{n}=10)$ & $-74 \pm 4(n=7)$ \\
\hline $\begin{array}{l}\text { Cardiac action } \\
\text { potential } \\
\text { Amplitude }(\mathrm{mV})\end{array}$ & $98 \pm 4(n=6)$ & $93 \pm 3(n=7)$ & $87 \pm 2(n=7)$ & $92 \pm 1(\mathrm{n}=10)$ & $97 \pm 4(\mathrm{n}=7)$ \\
\hline $\mathrm{APD}_{20}(\mathrm{~ms})$ & $9.5 \pm 0.7(n=6)$ & $\begin{array}{c}10.3 \pm 1.1 \\
(\mathrm{n}=7)\end{array}$ & $11.7 \pm 1.1(\mathrm{n}=7)$ & $14.5 \pm 1.2^{a}(\mathrm{n}=10)$ & $16.7 \pm 1.8^{a}(\mathrm{n}=7)$ \\
\hline $\mathrm{APD}_{50}(\mathrm{~ms})$ & $\begin{array}{l}24.0 \pm 1.5 \\
\quad(n=6)\end{array}$ & $\begin{array}{c}24.5 \pm 2.2 \\
(\mathrm{n}=7)\end{array}$ & $28.8 \pm 2.2(\mathrm{n}=7)$ & $37.3 \pm 2.6^{a}(\mathrm{n}=10)$ & $46.2 \pm 5.5^{a}(\mathrm{n}=7)$ \\
\hline $\mathrm{APD}_{90}(\mathrm{~ms})$ & $\begin{array}{c}66.6 \pm 3.1 \\
(n=6)\end{array}$ & $\begin{array}{c}65.7 \pm 3.4(\mathrm{n} \\
=7)\end{array}$ & $86.0 \pm 6.9(n=7)$ & $105.3 \pm 2.9^{a}(\mathrm{n}=10)$ & $109.4 \pm 5.8^{a}(\mathrm{n}=7)$ \\
\hline
\end{tabular}

$a_{\mathrm{p}}<0.05$ compared to UNX. 